\title{
Brewing Rutin-Enriched Lager Beer with Buckwheat Malt as Adjuncts
}

\author{
Yang Deng ${ }^{1,2+}$, Juho Lim ${ }^{2,3+}$, Gang-Hee Lee ${ }^{3}$, Thi Thanh Hanh Nguyen ${ }^{2}$, Yang Xiao ${ }^{1}$, Meizi Piao ${ }^{1}$, and \\ Doman $\mathrm{Kim}^{2,3 *}$ \\ ${ }^{1}$ College of Food Science and Engineering, Qingdao Agricultural University, Qingdao 266109, P.R. China \\ ${ }^{2}$ Institute of Food Industrialization, Institutes of Green Bio Science and Technology, Seoul National University, Pyeongchang 25354, \\ Republic of Korea \\ ${ }^{3}$ Graduate School of International Agricultural Technology and Center for Food and Bioconvergence, Seoul National University, \\ Pyeongchang 25354, Republic of Korea
}

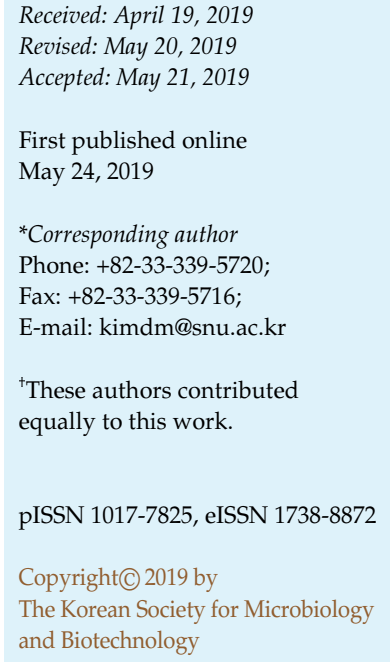

\begin{abstract}
Brewing with buckwheat as an ingredient has been proven to be successful in several previous studies. However, few studies have focused on the effects of buckwheat on the rutin content and antioxidant activity of beer. In order to develop a lager beer with high rutin content and desirable sensory characteristics, tartary buckwheat malt was used as a brewing adjunct. The results showed that the rutin-degrading enzyme was the key factor affecting the rutin content in the wort and beer. Compared to beer made using the common mashing method, the rutin content in the buckwheat beers produced using an improved mashing method was approximately 60 times higher. The total flavonoid contents in buckwheat beers also depended strongly on the mashing methods, ranging from 530.75 to $1,704.68 \mathrm{mg} \mathrm{QE} / \mathrm{l}$. The rutin-rich beers also showed better oxidative stability during forced-aging. Meanwhile, the buckwheat beers were found to be acceptable in terms of the main quality attributes, flavor, and taste.
\end{abstract}

Keywords: Buckwheat malt, flavonoid compounds, rutin, functional beer, oxidative stability

\section{Introduction}

Beer is most commonly brewed from barley malt, although other grain raw materials such as wheat and rice are also used [1,2]. During the brewing process, fermentation of the sugars from starch in the wort is used to produce ethanol and form carbonation in the resulting beer. Beer is rich in nutrients such as carbohydrates, amino acids, vitamins, minerals, phenolic compounds, etc. [3]. The main polyphenols in beer include phenolic acids, flavonoids, tannins, proanthocyanidins, and amino phenolic compounds [4]. They are originated from malt (70-80\%) and hops (20$30 \%$ ), and substantially contribute to the color, taste, and stability of a given beer [3]. Several epidemiological studies have suggested that regular and moderate beer consumption significantly reduces cardiovascular morbidity and mortality $[5,6]$. Other health benefits of beer include lower risks of dementia and cognitive impairment [5] as well as decreased risks of diabetes and osteoporosis [6].

Buckwheat (Fagopyrum spp.), a crop that is commonly cultivated in Asia as well as Central and Eastern Europe, shares similarities with barley. Buckwheat seed consists predominantly of edible starchy endosperm and a nonstarchy aleurone layer [7]. Common buckwheat (Fagopyrum esculentum) and tartary buckwheat (Fagopyrum tataricum) are the types of buckwheat cultivated for human consumption. As buckwheat does not form gluten, it is a common supplement for patients who suffer from coeliac disease [7]. It is also recognized as a good source of proteins with high biological value and balanced amino acid composition, lipid, dietary fiber, and minerals [7]. Combined with other medically beneficial compounds, such as flavonoids, fagopyrin, and buckwheat sterols, it has recently attracted increasing attention as an alternative crop for organic cultivation and as an ingredient for health food products [8]. Rutin (quercetin-3-rutinoside), the major 
flavonoid in buckwheat, serves as a bioactive ingredient in pharmaceuticals as a free radical scavenger [9], and it has remarkable anti-inflammatory as well as immunomodulatory effects [10]. No rutin is found in any cereals and pseudo-cereals except for buckwheat, so it may be used as a good source of dietary rutin [11, 12].

Recent studies have shown that buckwheat has the potential to be used as a raw material in the production of gluten-free beer $[13,14]$. However, all of these studies have found a significantly lower enzymatic activity in buckwheat malt than barley malt [14-16]. Due to the low levels of $\alpha$ - and $\beta$-amylase, mashing using $100 \%$ buckwheat malt without the addition of commercial enzymes can lead to undesirable properties such as low extract yields, high wort viscosities, and decreased rates of fermentation [1416]. Meanwhile, few studies have attempted to analyze the effect of buckwheat malt based on the rutin content and antioxidant activity of beer [17]. Therefore, the aim of the present work was to develop a lager beer with high rutin content by using buckwheat malt as an adjunct on a laboratory scale. In order to achieve this: i) the mixtures of barley malt and buckwheat malt in different proportions were mashed using different mashing programs, ii) the bioactive compound concentrations and oxidative stabilities of the obtained beers were determined, and finally, iii) the sensory qualities of these beers were evaluated.

\section{Materials and Methods}

\section{Materials}

Both tartary buckwheat and common buckwheat were harvested in 2018 and acquired from Bongpyeong (Korea). The Pilsner-type barley malt was purchased from Weyermann Specialty Malting Company (Germany). The dry lager yeasts (Saflager S-23) were purchased from Fermentis Ltd. (France). The Cascade hop pellets were obtained from Lupex GMBH (Hallertau, Germany).

\section{Micro-Brewing Trials}

Malting, milling, and mashing. The tartary buckwheat and common buckwheat were malted as follows: steeping $\left(20^{\circ} \mathrm{C} / 8 \mathrm{~h}\right)$, germination $\left(20^{\circ} \mathrm{C} / 88 \mathrm{~h}\right)$, and kilning $\left(60^{\circ} \mathrm{C} / 22 \mathrm{~h}\right)$ [12]. The milling of brewing materials was carried out immediately before mashing-in. A total of $4 \mathrm{~kg}$ of grains composed of barley malt and buckwheat malt in different proportions (100:0, 80:20, and 60:40) was prepared, then ground with a two-roller grist mill (Germany) at a setting of $0.2 \mathrm{~mm}$.

Two different methods of the mashing procedure, $A$ and $B$, were performed using a 25-liter laboratory mash bath (BIELMEIER Hausgeräte, $\mathrm{GmbH}$, Germany). Mashing method A, a widely used infusion mashing procedure involving four successive rests, was carried out as follows. First, the milled malt was mashed with water at $50^{\circ} \mathrm{C}$ to a volume ratio of $1: 4(\mathrm{w} / \mathrm{v})$, stirred, and maintained in this state for $20 \mathrm{~min}$. Afterwards, this mash was heated to $64^{\circ} \mathrm{C}$ at a rate of approximately $1^{\circ} \mathrm{C} / \mathrm{min}$, rested for $70 \mathrm{~min}$, heated again to $72^{\circ} \mathrm{C}$, and was left to rest for $20 \mathrm{~min}$. As the final step, the mash was heated up to $78^{\circ} \mathrm{C}$ and maintained for $10 \mathrm{~min}$. The other procedure, method $\mathrm{B}$, was the improved mashing method involving a total of five successive rests. First, the milled buckwheat malt was mixed with hot water at $80^{\circ} \mathrm{C}$, kept at the same temperature for $20 \mathrm{~min}$, and then cooled below $50^{\circ} \mathrm{C}$. Thereafter, a ground barley malt was added into this buckwheat mash and maintained at $50^{\circ} \mathrm{C}$ for $20 \mathrm{~min}$. A constant grist-to-liquor ratio of 1:4 (w/v) was utilized. The following three steps of the procedure were the same as the aforementioned mashing method $\mathrm{A}$, with the temperature-time regimes adopted on total mash of 64,72 , and $78^{\circ} \mathrm{C}$ with holding times of 70,20 , and $10 \mathrm{~min}$, respectively. The buckwheat adjunct beers were respectively brewed with the addition of 20 and $40 \%$ buckwheat malt using the two aforementioned mashing methods, while the beer made with $100 \%$ base barley malt was produced using only mashing method A and thus served as a control.

Analysis of $\alpha$-amylase and $\beta$-amylase activities. Both the $\alpha$-amylase and $\beta$-amylase activities were analyzed in the five worts after the treatment (of $64^{\circ} \mathrm{C}$ for $70 \mathrm{~min}$ ) during the mashing. To measure the $\alpha$-amylase activity, the standard method No. 303 of the International Association for Cereal Chemistry (ICC) was adopted using an enzyme kit (Megazyme, Bray, Ireland). The $\alpha$-amylase activity was calculated according to the enzyme manual instructions. The $\beta$-amylase activity was determined by adopting the method described in the $\beta$-amylase Megazyme enzyme kit and calculated according to the enzyme manual instructions.

Lautering and wort boiling. The mash was allowed to settle for a few minutes before the supernatant was transferred to the wort kettle. Next, the sediment was washed twice with hot water $\left(70^{\circ} \mathrm{C}\right)$ to achieve a final volume of $20 \mathrm{~L}$ of wort. The wort was then boiled for $60 \mathrm{~min}$, followed by the addition of hop pellets $(0.4 \mathrm{~g} / \mathrm{l})$ as well as whirlpool and chilling processes. The hop pellets were added in two stages. During the wort boiling process, $5 \mathrm{~g}$ of cascade pellets and $3 \mathrm{~g}$ of cascade pellets were added after $5 \mathrm{~min}$ boiling and after $40 \mathrm{~min}$ boiling, respectively.

Fermentation, filtration, and bottling. The final hopped wort (around $11^{\circ}$ Plato) was immediately transferred directly into $25 \mathrm{~L}$ steel tanks (Candirect, Duisburg, Germany) and stored at $15^{\circ} \mathrm{C}$. Prior to fermentation, $16 \mathrm{~g}$ of the yeasts, Saflager S-23, was added to the wort after rehydration according to the manufacturer's instructions. The primary fermentation lasted eight days at $10^{\circ} \mathrm{C}$ while the secondary fermentation lasted four days at $12^{\circ} \mathrm{C}$. The fermentation fluid was then filtered by centrifugation at 6,000 $\times g$ for $15 \mathrm{~min}$ in order to obtain the clarified beer. Finally, the beer was poured into $500 \mathrm{ml}$ amber glass bottles with flip caps and then stored at $4^{\circ} \mathrm{C}$ in the dark for 14 days before beginning the experiments. 
Forced-Aging Test and Antioxidant Capability Evaluation of Beer After the beer was prepared, the bottled fresh samples were aged in the dark under forced conditions at $40^{\circ} \mathrm{C}$ in a thermostatically controlled room. The antioxidant capacity was analyzed by DPPH radical scavenging activity and ferric reducing antioxidant power (FRAP) assays after $0,3,6,9,12$, and 15 days of forced-aging, respectively.

The DPPH radical scavenging activity of beer samples was determined using the stable 2,2-diphenyl-1-picrylhydrazyl reagent according to a previously described method [4] with minor modifications. Briefly, each type of diluted beer $(0.3 \mathrm{ml})$ was mixed with $2.7 \mathrm{ml}$ of DPPH ethanol solution $(100 \mu \mathrm{M})$. The mixture was then incubated in the dark for $1 \mathrm{~h}$ at room temperature. The absorbance of the samples was measured at a wavelength of $517 \mathrm{~nm}$ on a microplate. The trolox calibration curve was plotted as a function of the percentage of DPPH radical scavenging activity. The final results were expressed as trolox equivalents (TE) mmol/l beer. The determination of FRAP was carried out according to the method established by $\mathrm{He}, \mathrm{Du}$, Zhang, Wei, and Wang [18].

\section{Physicochemical Analyses of Standard Wort and Beer}

Standard wort analyses were performed according to the methods outlined by the Analytica European Brewery Convention (EBC) [15]. The original gravity, final alcohol content, residual sugar, $\mathrm{pH}$, and color of the degassed beers were measured using a DMA 4500 Density Analyzer and Alcolyser Plus (Anton Paar, Austria). The traditional and international recommended analyses of bitterness in beer in terms of international bitter units (IBU) was conducted at $275 \mathrm{~nm}$, using an acidic solvent extract of beer, by spectrophotometric measurement. Headspace gas chromatography (HS-GC) was employed to measure diacetyl, acetaldehyde, higher alcohols, and esters using the method described by Dong, et al. [19]. The isohumulone content of the beer samples was determined using reversed phase high-performance liquid chromatography (RP-HPLC) (Agilent 1100 Series, USA). The mobile phase consisted of the mixture of solvents $\mathrm{A}$ and $\mathrm{B}$. Solvent $\mathrm{A}$ was a mixture of ethanol and $5 \mathrm{mmol} / \mathrm{l}$ aqueous ammonium acetate solution (20:80, $\mathrm{v} / \mathrm{v}$ ) and solvent $\mathrm{B}$ was a mixture of acetonitrile and methanol $(60: 40, v / v)$. A $20 \mu \mathrm{l}$ aliquot of each beer sample was loaded and separated using an Agilent Eclipse XDB- $\mathrm{C}_{18}$ column $(4.6 \mathrm{~mm} \times$ $150 \mathrm{~mm}, 5 \mu \mathrm{m}$ particle size). Gradient elution was performed by increasing the concentration of solvent B from $16 \%$ to $40 \%$ over a period of $54 \mathrm{~min}$, then to $95 \%$ over an additional $6 \mathrm{~min}$ before returning to the initial conditions at a flow rate of $0.5 \mathrm{ml} / \mathrm{min}$. Elution was monitored by photodiode array detection at $256 \mathrm{~nm}$. In addition, foam stability was assessed according to the NIBEM value using the NIBEM tester (Haffmans, The Netherlands).

\section{Determination of Rutin and Quercetin Content}

One gram of each grain was extracted with $10 \mathrm{ml}$ of $70 \%$ (v/v) ethanol for $60 \mathrm{~min}$ and serially diluted in 10-fold steps with LCgrade methanol. The brewing intermediate products (hopped worts) and final degassed beer samples were mixed with the same volume of distilled water and deproteinated using LC-grade methanol. All of the samples were filtered using a $0.2-\mu \mathrm{m}$-pore-size membrane syringe filter (Pall Corporation, USA). Then, $1 \mu \mathrm{l}$ of each sample was injected into UPLC-MS (Waters H-class equipped with QDa detector, MA, USA) on a 1.7- $\mu \mathrm{m} \mathrm{BEH} \mathrm{C}{ }_{18}$ column (2.1 mm $\times 150 \mathrm{~mm}$ ) for the simultaneous determination of rutin and quercetin content, as described in a previous report of ours [20].

\section{Total Flavonoid Content Assay}

Total flavonoid content was measured by the aluminium chloride colorimetric assay [21]. An aliquot $(1 \mathrm{ml})$ of a beer sample or standard solution of quercetin was added into a $10 \mathrm{ml}$ volumetric flask containing $4 \mathrm{ml}$ of distilled water. Then, $0.3 \mathrm{ml}$ of $5 \% \mathrm{NaNO}_{2}$ was added to the flask, then $0.3 \mathrm{ml}$ of $10 \% \mathrm{AlCl}_{3}$ was added after five minutes. After another five minutes, $2 \mathrm{ml}$ of $1 \mathrm{~mol} / 1 \mathrm{NaOH}$ solution was added, and the final volume of the mixture was then made up to $10 \mathrm{ml}$ with distilled water. The mixture was allowed to stand for $15 \mathrm{~min}$ before its absorbance was measured against the blank at $510 \mathrm{~nm}$. The total flavonoid content was expressed as quercetin equivalents (QE) $\mathrm{mg} / \mathrm{l}$ beer.

\section{Rutin-Degrading Enzyme Activity}

The rutin-degrading enzyme activity was evaluated using the method outlined by Chen and $\mathrm{Gu}$ [22]. Briefly, the untreated and heat-treated (at $80^{\circ} \mathrm{C}$ for $20 \mathrm{~min}$ ) tartary buckwheat malt powders $(2 \mathrm{~g})$ were extracted in $30 \mathrm{ml}$ of $0.2 \mathrm{M}$ acetate buffer, $\mathrm{pH} 4.0$ at $4^{\circ} \mathrm{C}$ for $3 \mathrm{~h}$. Following centrifugation at $8,991 \times g$ for $15 \mathrm{~min}$ at $4^{\circ} \mathrm{C}$, the supernatant of each sample was collected and stored at $4^{\circ} \mathrm{C}$. Then, $1.6 \mathrm{ml}$ of rutin solution $(100 \mu \mathrm{g} / \mathrm{ml})$ and $0.4 \mathrm{ml}$ of the supernatant were mixed and incubated at $50^{\circ} \mathrm{C}$ for $3 \mathrm{~min}$. The enzymatic reaction was stopped using $8 \mathrm{ml}$ of methanol. The activity of rutin-degrading enzyme was evaluated by measuring the content of quercetin converted from rutin. The quercetin content was measured by UPLC-MS in the manner described above.

\section{Sensory Analyses}

The sensory evaluation was performed by a well-trained panel of ten evaluators, in accordance with our previous work [23]. The sensory attributes included the following three aspects: odor (total intensity, malty aroma, hop aroma, and nutty aroma), mouth sensations (freshness and fullness), taste (sweetness, bitter intensity, quality of bitterness, and purity of taste) and total acceptability. Each sensory attribute was graded from 1 (worst grade) to 5 (best grade) and the average value of the ten judges was used for the final score.

\section{Statistical Analysis}

Data are presented as mean \pm standard deviation of three independent replicates. Statistical comparisons were made by one-way analysis of variance followed by Tukey's comparison tests. Values were considered to be significant when $p<0.05$. 
Table 1. Determination of the rutin, quercetin content and total flavonoids in the buckwheat malts, final worts, and beers*

\begin{tabular}{lcccc}
\hline \multicolumn{1}{c}{ Samples } & $\begin{array}{c}\text { Mashing } \\
\text { conditions }\end{array}$ & $\begin{array}{c}\text { Rutin content } \\
(\mathrm{mg} / \mathrm{g} \text { or } \mathrm{mg} / 100 \mathrm{ml})\end{array}$ & $\begin{array}{c}\text { Quercetin content } \\
(\mathrm{mg} / 100 \mathrm{ml})\end{array}$ & $\begin{array}{c}\text { Total flavonoid content } \\
(\mathrm{mg} \text { QE } / \mathrm{l})\end{array}$ \\
\hline $\begin{array}{l}\text { Common buckwheat malt } \\
\text { Tartary buckwheat malt }\end{array}$ & $/$ & $0.13 \pm 0.07 \mathrm{a}$ & $0.02 \pm 0.01 \mathrm{a}$ & $\mathrm{ND}$ \\
100\% barley malt reference wort & Method A & $6.70 \pm 0.03 \mathrm{~b}$ & $5.12 \pm 0.05 \mathrm{~b}$ & $\mathrm{ND}$ \\
$100 \%$ barley malt reference beer & & $0.58 \pm 0.02 \mathrm{c}$ & $0.15 \pm 0.01 \mathrm{c}$ & $294.75 \pm 15.42 \mathrm{a}$ \\
$20 \%$ buckwheat malt wort & Method A & $1.60 \pm 1.39 \mathrm{c}$ & $0.13 \pm 0.01 \mathrm{c}$ & $303.69 \pm 20.14 \mathrm{a}$ \\
$20 \%$ buckwheat malt beer & & $0.34 \pm 0.02 \mathrm{c}$ & $4.93 \pm 0.06 \mathrm{~d}$ & $516.75 \pm 28.19 \mathrm{~b}$ \\
$40 \%$ buckwheat malt wort & & $0.34 \pm 0.01 \mathrm{c}$ & $2.47 \pm 0.06 \mathrm{~d}$ & $530.75 \pm 19.13 \mathrm{~b}$ \\
$40 \%$ buckwheat malt beer & & $0.65 \pm 0.02 \mathrm{c}$ & $4.39 \pm 0.06 \mathrm{~d}$ & $876.75 \pm 30.44 \mathrm{c}$ \\
$20 \%$ buckwheat malt wort & Method B & $0.55 \pm 0.01 \mathrm{c}$ & $2.62 \pm 0.04 \mathrm{~d}$ & $855.30 \pm 21.95 \mathrm{c}$ \\
$20 \%$ buckwheat malt beer & & $23.40 \pm 0.10 \mathrm{~d}$ & $2.97 \pm 0.04 \mathrm{~d}$ & $1,096.45 \pm 40.55 \mathrm{~d}$ \\
$40 \%$ buckwheat malt wort & & $21.00 \pm 0.10 \mathrm{~d}$ & $1.82 \pm 0.04 \mathrm{~d}$ & $1,180.23 \pm 34.06 \mathrm{~d}$ \\
$40 \%$ buckwheat malt beer & & $41.40 \pm 1.20 \mathrm{e}$ & $3.91 \pm 0.05 \mathrm{~d}$ & $1,758.46 \pm 38.98 \mathrm{e}$ \\
\hline
\end{tabular}

*Values are the means \pm standard deviations of triplicate measurements. Different letters following the numbers on the same line indicate means separation at $p<0.05$. ND: no detection.

\section{Results and Discussion}

\section{Rutin and Quercetin Contents of Different Buckwheat Species}

Different cultivars of buckwheat may have different contents of rutin [11]. Therefore, the quantitative analyses of rutin and quercetin in the two buckwheat malts used in our study were compared. The average rutin and quercetin contents differ significantly between the common buckwheat malt and the tartary buckwheat malt. The rutin and quercetin contents in the tartary buckwheat malt were almost 52 and 250 times more than those in common buckwheat malt, respectively (Table 1). Many studies have investigated the difference in rutin content between common buckwheat and tartary buckwheat [11, 24]. Our data were similar to the findings of these previous studies. Tartary buckwheat generally contains high levels of rutin in its seeds (about $1 \mathrm{mg} / \mathrm{g}$ dry weight) [7]. Hence, in this work, tartary buckwheat malt was chosen as the brewing adjunct to produce the rutin-rich beer.

\section{Wort Analyses}

The effects of the two different mashing methods (methods A and B) on buckwheat wort properties were evaluated by determining the viscosity, $\mathrm{pH}$, free amino nitrogen (FAN), and total carbohydrate profile. As shown in Table 2, the wort viscosity increased significantly when replacing $20 \%$ or $40 \%$ malted barley with the tartary buckwheat malt using both mashing methods $\mathrm{A}$ and $\mathrm{B}$.
Although the viscosity values of the buckwheat worts differed slightly, they were all within the range (1-2 $\mathrm{mPa} s)$ that is not believed to cause brewing problems when using the buckwheat as an adjunct [14]. By contrast, there was no significant change in the $\mathrm{pH}$ value of the four buckwheat worts as compared to the $100 \%$ malted barley wort as has been previously found $[15,16]$.

FAN is an important general measure of these nutrients, which constitute the nitrogen that yeast can assimilate during brewery fermentation [15]. Therefore, the amount of FAN in wort affects the yeast growth and the final beer flavor properties [15]. In this work, substitution of $20 \%$ barley malt with buckwheat malt resulted in a significantly declined FAN level of the final worts produced using both mashing methods from $235 \mathrm{mg} / 1$ (100\% malted barley) to 203-210 mg/l (Table 2). The different mashing procedures scarcely affected the FAN level in the buckwheat worts. Doubling the adjunct concentration from $20 \%$ to $40 \%$ malted buckwheat led to a further reduction in wort FAN to $179-186 \mathrm{mg} / \mathrm{l}$. However, it has been found that FAN levels of above $160 \mathrm{mg} / 1$ are adequate for optimal yeast growth and efficient fermentation [25]. The total carbohydrate profile is summarized in Table 2. Compared to the $100 \%$ malted barley wort, no significant differences were observed in the total fermentable sugar concentration in all of the buckwheat wort samples. Statistical differences were only observed for maltose and maltotriose concentration $(p<0.05)$. This could be due to the decreased $\alpha$-amylase and $\beta$-amylase activities present in buckwheat 
Table 2. Characteristics of the hopped worts produced with barley malt and buckwheat malt in different proportions using two mashing methods*.

\begin{tabular}{|c|c|c|c|c|c|}
\hline Properties & $\begin{array}{l}100 \% \text { barley malt } \\
\text { reference wort }\end{array}$ & $\begin{array}{c}20 \% \text { buckwheat malt } \\
\text { wort (method } \mathrm{A})\end{array}$ & $\begin{array}{c}20 \% \text { buckwheat malt } \\
\text { wort (method B) }\end{array}$ & $\begin{array}{c}40 \% \text { buckwheat malt } \\
\text { wort (method A) }\end{array}$ & $\begin{array}{c}40 \% \text { buckwheat malt } \\
\text { wort (method B) }\end{array}$ \\
\hline Viscosity (mPa s) & $1.24 \pm 0.01 \mathrm{a}$ & $1.58 \pm 0.01 b$ & $1.79 \pm 0.02 b$ & $1.95 \pm 0.02 \mathrm{c}$ & $1.86 \pm 0.01 \mathrm{c}$ \\
\hline $\mathrm{pH}$ & $5.66 \pm 0.01 \mathrm{a}$ & $5.72 \pm 0.01 \mathrm{a}$ & $5.69 \pm 0.01 \mathrm{a}$ & $5.68 \pm 0.02 a$ & $5.70 \pm 0.02 \mathrm{a}$ \\
\hline Free amino nitrogen (FAN) (mg/l) & $235 \pm 4 a$ & $210 \pm 5 b$ & $203 \pm 2 b$ & $179 \pm 4 c$ & $186 \pm 5 c$ \\
\hline \multicolumn{6}{|l|}{ Fermentable sugar composition } \\
\hline Glucose $(\mathrm{g} / \mathrm{l})$ & $19.7 \pm 0.5 \mathrm{a}$ & $20.1 \pm 0.2 \mathrm{a}$ & $19.9 \pm 0.3 a$ & $20.3 \pm 0.3 a$ & $20.4 \pm 0.1 \mathrm{a}$ \\
\hline Fructose $(\mathrm{g} / \mathrm{l})$ & $1.2 \pm 0.1 \mathrm{a}$ & $0.8 \pm 0.1 \mathrm{a}$ & $0.7 \pm 0.0 \mathrm{a}$ & $0.6 \pm 0.2 \mathrm{a}$ & $0.8 \pm 0.1 \mathrm{a}$ \\
\hline Sucrose $(\mathrm{g} / \mathrm{l})$ & $1.9 \pm 0.3 a$ & $2.0 \pm 0.2 \mathrm{a}$ & $1.8 \pm 0.2 \mathrm{a}$ & $1.8 \pm 0.1 \mathrm{a}$ & $1.9 \pm 0.2 \mathrm{a}$ \\
\hline Maltose $(\mathrm{g} / \mathrm{l})$ & $56.3 \pm 2.1 \mathrm{a}$ & $52.0 \pm 1.5 b$ & $51.4 \pm 1.6 b$ & $50.7 \pm 1.0 \mathrm{bc}$ & $50.9 \pm 1.8 \mathrm{bc}$ \\
\hline Maltotriose (g/l) & $10.1 \pm 1.0 \mathrm{a}$ & $13.2 \pm 0.8 b$ & $13.0 \pm 0.9 b$ & $14.0 \pm 0.6 \mathrm{c}$ & $14.1 \pm 1.0 \mathrm{c}$ \\
\hline
\end{tabular}

*Values are the means \pm standard deviations of triplicate measurements. Means within the same property followed by a different letter are significantly different $(p<0.05)$.

malt compared to that of the barley malt [16]. The $\alpha$-amylase and $\beta$-amylase activities in the five worts after the mashing-in step (at $64^{\circ} \mathrm{C}$ for $70 \mathrm{~min}$ ) were also analyzed in our study. The $100 \%$ malted barley wort exhibited increased $\alpha$-amylase activity and an especially high $\beta$-amylase activity when compared to those of the malted buckwheat worts (Table 3 ). The above results indicate that the main wort quality attributes were acceptable when replacing partial barley malt with buckwheat malt, and that yeast performance was not affected.

\section{Beer Analyses}

The main physicochemical characteristics of these beer samples produced with barley malt and buckwheat malt in different proportions using two mashing methods were compared in the study. As shown in Table 4, the original gravity, ethanol content, residual sugar and $\mathrm{pH}$ were similar among all five of the beers. However, the beer color value increased from 3.9 EBC (100\% barley malt reference) to around $4.5 \mathrm{EBC}$ when using $20 \%$ of the tartary buckwheat malt. Doubling the adjunct amount from $20 \%$ to $40 \%$ buckwheat malt led to a further increase in beer color to about 5.1 EBC. The bitterness and colloidal haze values of buckwheat beers also increased slightly as compared to those of the $100 \%$ malted barley beer. Because the same hopping regime was used, the isohumulone content was similar among the five beers.

Foam is one of the first indicators of beer quality encountered by a consumer, and stability is affected by the levels of proteins present in the beer [26]. The foam stabilities of the beers produced with $20 \%$ or $40 \%$ malted buckwheat using both mashing methods A and B were lower than that of $100 \%$ barley malt beer (Table 4). Compared to mashing method A, the beer produced using mashing method B exhibited better foam stability when the same amount of buckwheat malt was used. De Meo and his colleagues also noted the reduction in beer foam stability when using $100 \%$ buckwheat malt, which was most likely caused by the reduced amounts of total soluble nitrogen and high-molecular-weight proteins [13]. Nevertheless, the foam stability levels of these buckwheat beers obtained in our study were still acceptable.

Higher alcohols and esters are known to make crucial contributions to the characteristic flavor and aroma in beer [23]. Among them, esters such as ethyl acetate, isoamyl acetate, ethyl hexanoate, and ethyl caprylate are responsible for the "fruity" flavor [19]. As shown in Table 4, the contents of ethyl acetate and isoamyl acetate in the $20 \%$

Table 3. Analyses of $\alpha$-amylase and $\beta$-amylase activities in the five worts.

\begin{tabular}{|c|c|c|c|c|c|}
\hline Enzyme activities & $\begin{array}{l}100 \% \text { barley malt } \\
\text { reference wort }\end{array}$ & $\begin{array}{c}20 \% \text { buckwheat malt } \\
\text { wort (method A) }\end{array}$ & $\begin{array}{c}20 \% \text { buckwheat malt } \\
\text { wort (method B) }\end{array}$ & $\begin{array}{c}40 \% \text { buckwheat malt } \\
\text { wort (method } \mathrm{A})\end{array}$ & $\begin{array}{c}40 \% \text { buckwheat malt } \\
\text { wort (method B) }\end{array}$ \\
\hline$\alpha$-amylase $\left(10^{3} \mathrm{U} / 1\right)$ & $8.0 \pm 0.2 a$ & $7.8 \pm 0.1 \mathrm{a}$ & $7.7 \pm 0.2 \mathrm{a}$ & $7.5 \pm 0.3 a$ & $7.5 \pm 0.2 \mathrm{a}$ \\
\hline
\end{tabular}

*Values are the means \pm standard deviations of triplicate measurements. Means within the same enzyme activity followed by a different letter are significantly different $(p<0.05)$. 
Table 4. Main chemical and physical attributes of finished beers produced with barley malt and buckwheat malt in different proportions using two mashing methods*.

\begin{tabular}{lccccc}
\hline \multicolumn{1}{c}{ Properties } & $\begin{array}{c}100 \% \text { barley malt } \\
\text { reference beer }\end{array}$ & $\begin{array}{c}20 \% \text { buckwheat malt } \\
\text { beer (method A) }\end{array}$ & $\begin{array}{c}20 \% \text { buckwheat malt } \\
\text { beer (method B) }\end{array}$ & $\begin{array}{c}40 \% \text { buckwheat malt } \\
\text { beer (method A) }\end{array}$ & $\begin{array}{c}40 \% \text { buckwheat malt } \\
\text { beer (method B) }\end{array}$ \\
\hline Original gravity ( ${ }^{\circ}$ Plato) & $11.06 \pm 0.03 \mathrm{a}$ & $11.10 \pm 0.03 \mathrm{a}$ & $11.08 \pm 0.02 \mathrm{a}$ & $11.05 \pm 0.02 \mathrm{a}$ & $11.09 \pm 0.02 \mathrm{a}$ \\
Ethanol content $(\% \mathrm{~V} / \mathrm{v})$ & $4.6 \pm 0.1 \mathrm{a}$ & $4.7 \pm 0.1 \mathrm{a}$ & $4.6 \pm 0.0 \mathrm{a}$ & $4.5 \pm 0.1 \mathrm{a}$ & $4.7 \pm 0.0 \mathrm{a}$ \\
Residual sugar $\left({ }^{\circ} \mathrm{Bx}\right)$ & $6.05 \pm 0.02 \mathrm{a}$ & $6.07 \pm 0.03 \mathrm{a}$ & $6.05 \pm 0.01 \mathrm{a}$ & $6.06 \pm 0.01 \mathrm{a}$ & $6.07 \pm 0.02 \mathrm{a}$ \\
$\mathrm{pH}$ & $4.43 \pm 0.04 \mathrm{a}$ & $4.46 \pm 0.07 \mathrm{a}$ & $4.44 \pm 0.05 \mathrm{a}$ & $4.45 \pm 0.04 \mathrm{a}$ & $4.46 \pm 0.05 \mathrm{a}$ \\
Color $(\mathrm{EBC})$ & $3.9 \pm 0.0 \mathrm{a}$ & $4.5 \pm 0.1 \mathrm{~b}$ & $4.4 \pm 0.1 \mathrm{~b}$ & $5.0 \pm 0.2 \mathrm{c}$ & $5.1 \pm 0.2 \mathrm{c}$ \\
Bitterness $(\mathrm{IBU})$ & $10.25 \pm 0.12 \mathrm{a}$ & $11.33 \pm 0.09 \mathrm{~b}$ & $11.34 \pm 0.11 \mathrm{~b}$ & $11.37 \pm 0.10 \mathrm{~b}$ & $11.42 \pm 0.09 \mathrm{~b}$ \\
Isohumulone content & $8.93 \pm 0.05 \mathrm{a}$ & $9.04 \pm 0.03 \mathrm{a}$ & $9.01 \pm 0.04 \mathrm{a}$ & $8.96 \pm 0.03 \mathrm{a}$ & $9.02 \pm 0.06 \mathrm{a}$ \\
Colloidal haze $(\mathrm{EBC})$ & $0.15 \pm 0.03 \mathrm{a}$ & $0.21 \pm 0.04 \mathrm{ab}$ & $0.25 \pm 0.05 \mathrm{~b}$ & $0.24 \pm 0.04 \mathrm{bc}$ & $0.28 \pm 0.03 \mathrm{c}$ \\
Foam stability $(\mathrm{s} / 3 \mathrm{~cm})$ & $227 \pm 5 \mathrm{a}$ & $213 \pm 4 \mathrm{~b}$ & $218 \pm 4 \mathrm{bc}$ & $201 \pm 2 \mathrm{~d}$ & $209 \pm 4 \mathrm{e}$ \\
Diacetyl $(\mu \mathrm{g} / \mathrm{l})$ & $83.4 \pm 2.5 \mathrm{a}$ & $85.7 \pm 1.8 \mathrm{a}$ & $80.9 \pm 2.1 \mathrm{a}$ & $86.7 \pm 1.9 \mathrm{a}$ & $84.4 \pm 2.0 \mathrm{a}$ \\
Acetaldehyde $(\mathrm{mg} / \mathrm{l})$ & $6.75 \pm 0.54 \mathrm{a}$ & $7.12 \pm 0.33 \mathrm{a}$ & $6.42 \pm 0.50 \mathrm{a}$ & $7.01 \pm 0.46 \mathrm{a}$ & $6.88 \pm 0.38 \mathrm{a}$ \\
Ethyl acetate $(\mathrm{mg} / \mathrm{l})$ & $12.18 \pm 0.31 \mathrm{a}$ & $13.90 \pm 0.22 \mathrm{~b}$ & $14.02 \pm 0.34 \mathrm{~b}$ & $14.69 \pm 0.26 \mathrm{c}$ & $14.73 \pm 0.30 \mathrm{c}$ \\
Isoamyl acetate $(\mathrm{mg} / \mathrm{l})$ & $0.99 \pm 0.15 \mathrm{a}$ & $1.10 \pm 0.12 \mathrm{ab}$ & $1.12 \pm 0.24 \mathrm{ab}$ & $1.43 \pm 0.21 \mathrm{bc}$ & $1.58 \pm 0.25 \mathrm{c}$ \\
Ethyl hexanoate $(\mathrm{mg} / \mathrm{l})$ & $0.17 \pm 0.04 \mathrm{a}$ & $0.13 \pm 0.05 \mathrm{a}$ & $0.14 \pm 0.06 \mathrm{a}$ & $0.13 \pm 0.05 \mathrm{a}$ & $0.12 \pm 0.04 \mathrm{a}$ \\
Ethyl caprylate $(\mathrm{mg} / \mathrm{l})$ & $0.19 \pm 0.08 \mathrm{a}$ & $0.16 \pm 0.07 \mathrm{a}$ & $0.17 \pm 0.09 \mathrm{a}$ & $0.16 \pm 0.07 \mathrm{a}$ & $0.15 \pm 0.08 \mathrm{a}$ \\
Propanol $(\mathrm{mg} / \mathrm{l})$ & $8.12 \pm 0.31 \mathrm{a}$ & $9.15 \pm 0.18 \mathrm{~b}$ & $8.84 \pm 0.19 \mathrm{c}$ & $9.11 \pm 0.22 \mathrm{bc}$ & $9.07 \pm 0.24 \mathrm{bc}$ \\
Isobutanol $(\mathrm{mg} / \mathrm{l})$ & $10.10 \pm 0.15 \mathrm{a}$ & $9.99 \pm 0.12 \mathrm{a}$ & $10.05 \pm 0.31 \mathrm{a}$ & $10.12 \pm 0.10 \mathrm{a}$ & $10.09 \pm 0.11 \mathrm{a}$ \\
Isoamyl alcohol $(\mathrm{mg} / \mathrm{l})$ & $53.81 \pm 0.40 \mathrm{a}$ & $55.12 \pm 0.41 \mathrm{~b}$ & $56.25 \pm 0.40 \mathrm{~b}$ & $56.07 \pm 0.25 \mathrm{~b}$ & $56.10 \pm 0.28 \mathrm{~b}$ \\
\hline
\end{tabular}

*Values are the means \pm standard deviations of triplicate measurements. Means within the same property followed by a different letter are significantly different $(p<0.05)$.

buckwheat beers produced using both mashing methods A and B were slightly increased, whereas the ethyl hexanoate and ethyl caprylate contents were scarcely affected as compared to those of the control beer. As the amount of buckwheat malt increased, the concentrations of ethyl acetate and isoamyl acetate were increased to 14.73 and $1.58 \mathrm{mg} / \mathrm{l}$, respectively. Regarding the higher alcohols, except for isobutanol, a slight decrease was obtained in all four of the buckwheat beers as compared to the $100 \%$ malted barley, which was a reference. Furthermore, the contents of diacetyl and acetaldehyde were similar among all five of these beer samples.

Rutin, Quercetin, and Total Flavonoid Content in Buckwheat Worts and Beers

The results of rutin, quercetin, and total flavonoid contents in buckwheat worts and beers are presented in Table 1. The rutin content varied significantly in the four buckwheat wort samples depending on the mashing conditions. Since the buckwheat worts contain at least $20 \%$ buckwheat malt, the expected amount of rutin in the final buckwheat worts should be higher than that in $100 \%$ malted barley wort. However, there were only very small contents of rutin in the $20 \%$ and $40 \%$ buckwheat worts prepared using mashing method A. By contrast, the actual quantity of rutin extracted from the $20 \%$ buckwheat wort produced using method B reached $23.40 \mathrm{mg} / 100 \mathrm{ml}$. With an increasing amount of buckwheat malt, the rutin content further increased to $41.40 \mathrm{mg} / 100 \mathrm{ml}$. A possible explanation for this is the presence of the rutin-degrading enzyme, flavonol 3-glucosidase (f3g). The enzyme f3g was originally isolated from tartary buckwheat [27], but has recently also been found in common buckwheat grain [28]. The existence of $\mathrm{f} 3 \mathrm{~g}$ in buckwheat reduces the extraction and utilization of rutin by catalyzing the conversion rutin into quercetin [29]. This might explain why the $20 \%$ and $40 \%$ buckwheat worts had substantially higher quercetin contents (4.93 and $4.39 \mathrm{mg} / 100 \mathrm{ml}$, respectively) than the $100 \%$ malted barley control wort $(0.15 \mathrm{mg} / 100 \mathrm{ml})$. However, the stability of rutin against oxidative degradation was much higher than its degradation product quercetin [28]. Kreft et al. [17] also noted that almost no rutin could be detected in commercial buckwheat beer and vinegar products. Additionally, previous studies have reported that the activity of $\mathrm{f} 3 \mathrm{~g}$ was 
optimal at $40-50^{\circ} \mathrm{C}$ and $\mathrm{pH} 5.0[27,28]$. The optimal temperature and $\mathrm{pH}$ are extremely similar to the mashing conditions involved in the first step of method A. Consequently, it appeared possible that rutin was degraded by $\mathrm{f} 3 \mathrm{~g}$ in the common mashing process. In contrast to method $\mathrm{A}$, the high temperature $\left(80^{\circ} \mathrm{C}\right)$ treatment in this first step of mashing method $\mathrm{B}$ appeared to lead to the inactivation of $\mathrm{f3g}$. These conjectures were further confirmed by the fact that the f3g enzyme activity could still be detected in the untreated buckwheat malt, rather than in the heat-treated (at $80^{\circ} \mathrm{C}$ for $20 \mathrm{~min}$ ) buckwheat malt (data not shown). Moreover, similar amounts of quercetin were found in the $20 \%$ and $40 \%$ buckwheat beers produced using mashing method B after rutin degradation. This is potentially related to the water solubility of quercetin, as it is known that quercetin is extremely lipophilic in nature and sparingly soluble in water [7].

Similarly, regarding the rutin content, the total flavonoid content in buckwheat wort samples depended strongly on the mashing methods, ranging from 516.75 to $1,758.46 \mathrm{mg}$ $\mathrm{QE} / 1$. Compared to mashing method A, the total flavonoid content was significantly greater in the worts produced using method B. With increasing amount of buckwheat malt (from $20 \%$ to $40 \%$ ), the total flavonoid content increased as well. In addition, no significant changes were observed in the concentrations of rutin, quercetin, and total flavonoids between the worts and their corresponding finished beers. Among these beer samples, the highest rutin and total flavonoid content $(617.45 \mathrm{mg} / 1$ and 1,704.68 mg QE/l, respectively) were both obtained in the $40 \%$ buckwheat beer produced using mashing method $\mathrm{B}$.

\section{Oxidative Stability of Beers}

In general, the tests measuring the antioxidant capacity of beer can be divided into two major categories: tests measuring the 'radical quenching ability,' such as DPPH assay [4], and other tests measuring the 'reducing ability,' such as FRAP assay [3]. According to the literature, the simultaneous use of at least two discrete methods is proposed to quantify the total antioxidant capacity [30,31]. Changes in the antiradical and reducing potentials of the five beer samples as a result of forced-aging were thus investigated using DPPH and FRAP assays (Fig. 1).

DPPH radicals have been widely used as model systems to investigate the radical-scavenging abilities of antioxidant compounds [4, 32,33]. DPPH radical scavenging activity is therefore important to flavor stability, because beer aging is typically considered as the formation of 3-methylbutanal, trans-2-nonenal, and other saturated and unsaturated
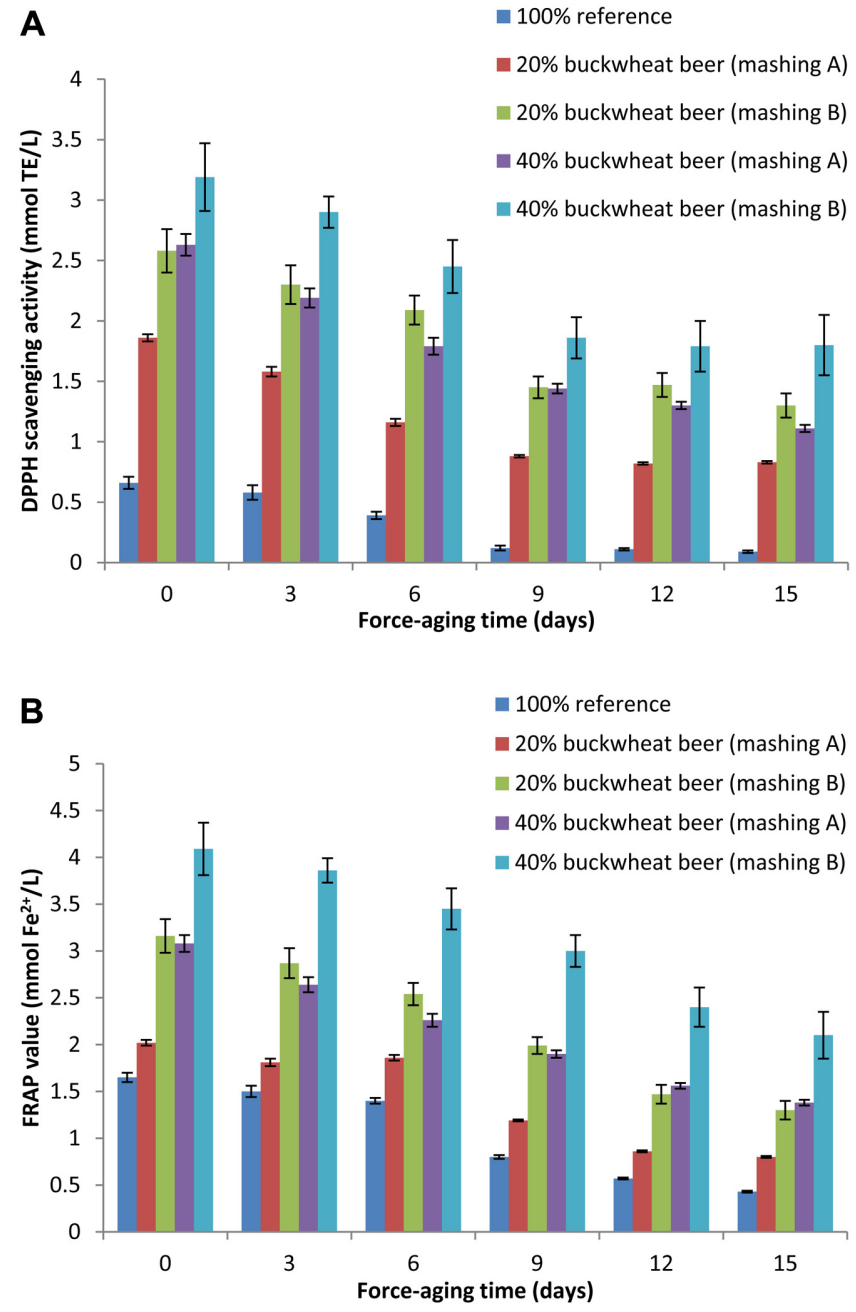

Fig. 1. Changes in 2,2-diphenyl-1-picrylhydrazyl (DPPH) scavenging activity (A) and ferric reducing antioxidant power (FRAP) value (B) in different beer samples during a 15-day forced-aging period.

aldehydes due to lipid oxidation [34,35]. As shown in Fig. 1, the activity values of the five fresh beer samples (on day 0) ranged from 0.66 to $3.19 \mathrm{mmol} \mathrm{TE} /$ l. Significant differences in the DPPH radical scavenging activity of the four buckwheat beers were also evident depending on the mashing conditions with the highest level in the $40 \%$ buckwheat beer produced using mashing method B. Under the same mashing conditions, the DPPH radical scavenging activity was enhanced with an increase in the amount of buckwheat malt from $20 \%$ to $40 \%$. The DPPH radical scavenging activity of each beer sample declined rapidly within the first nine days, and subsequently gradually stabilized. All four of the buckwheat beers exhibited 
stronger DPPH radical scavenging activities than the $100 \%$ malted barley beer on the same day along the forced-aging period. Compared to method $\mathrm{A}$, the DPPH radical scavenging activities in the buckwheat beers produced using mashing method B were greater after 15 days of forced-aging when using the same amount of buckwheat malt, indicating a considerable effect of the mashing conditions on the DPPH radical scavenging activity of beer. Reducing power is also believed to be associated with antioxidant activity and can serve as an important indicator $[3,18]$. Similar observations were found in the results of FRAP activity analysis. Among these samples, the largest decrease in FRAP value was obtained in the $100 \%$ malted barley reference after 15 days of forced-aging. Throughout the entire forced-aging period, the buckwheat beers made using mashing method B were found to have significantly higher FRAP activities than those made using method A when the same amount of buckwheat malt was used. The FRAP values ranged from $0.43 \mathrm{mmol} \mathrm{Fe}^{2+} / 1$ for the reference to $2.10 \mathrm{mmol} \mathrm{Fe}^{2+} / 1$ for the $40 \%$ buckwheat beer produced using mashing method B at forced-aging day 15.

The data showed a good correlation between antioxidant activity and rutin content or total flavonoid content in the buckwheat beers. As was expected, the beer with the highest content of rutin and total flavonoids had the greatest oxidative stability during forced-aging. Numerous studies have evaluated the antioxidant capacities of various beers [3, 4, 33]. These published results have reported that the antioxidant activity of beer is closely related to the content of polyphenols and flavonoids. Piazzon et al. [3] compared the antioxidant activities of different types of beer using the FRAP method and found a higher oxidative stability in polyphenol-enriched beer. Ducruet, et al. [36] mentioned that enriching beer with fruits such as goji berries can add new flavors, but can also increase the content of bioactive compounds and the oxidative stability of beer. In Belgium, there is a long tradition of producing lambic beers with cherry, strawberry, or raspberry added [37].

In addition, as Slimestad and Verheul [38] reported, rutin exhibited a substantially stronger antioxidant power in the FRAP assay, which was about twice that of ascorbic acid at concentrations of $1,000 \mu \mathrm{M}$, and 2.5 times that of chalconaringenin. The order of antioxidant capacity in the FRAP assay was found to be rutin $>$ ascorbic acid > chalconaringenin. They also indicated that rutin had more effective antioxidant activity than trolox and chalconaringenin in DPPH assay [38]. Yang, Guo, and Yuan [39] recently compared the ability of rutin to effectively scavenge the DPPH radical to the corresponding abilities of ascorbic acid and butylated hydroxytoluene. Their results revealed that at a concentration of $0.05 \mathrm{mg} / \mathrm{ml}$, rutin, ascorbic acid, and butylated hydroxytoluene showed $90.4 \%, 92.8 \%$, and $58.8 \%$ inhibitions, respectively.

\section{Sensory Evaluation}

In order to further explore the effect of buckwheat malt on beer quality, the organoleptic characteristics of several samples were assessed. As shown in Table 5, these fresh

Table 5. The sensory profiles of different beers produced with barley malt and buckwheat malt in different proportions using two mashing methods.

\begin{tabular}{lccccc}
\hline Sensory attributes & $\begin{array}{c}100 \% \text { barley malt } \\
\text { reference beer }\end{array}$ & $\begin{array}{c}20 \% \text { buckwheat malt } \\
\text { beer (method A) }\end{array}$ & $\begin{array}{c}20 \% \text { buckwheat malt } \\
\text { beer (method B) }\end{array}$ & $\begin{array}{c}40 \% \text { buckwheat malt } \\
\text { beer (method A) }\end{array}$ & $\begin{array}{c}40 \% \text { buckwheat malt } \\
\text { beer (method B) }\end{array}$ \\
\hline Total odor intensity & $4.0 \mathrm{a}$ & $3.5 \mathrm{ab}$ & $3.0 \pm 0.5 \mathrm{~b}$ & $3.5 \pm 0.5 \mathrm{ab}$ & $3.5 \mathrm{ab}$ \\
Malty aroma & $4.0 \mathrm{a}$ & $3.5 \mathrm{ab}$ & $3.5 \mathrm{ab}$ & $3.0 \mathrm{~b}$ & $3.5 \pm 0.5 \mathrm{ab}$ \\
Hop aroma & $4.0 \mathrm{a}$ & $4.0 \mathrm{a}$ & $3.5 \mathrm{a}$ & $3.5 \mathrm{a}$ & $3.5 \mathrm{a}$ \\
Nutty aroma & $1.5 \pm 0.5 \mathrm{c}$ & $2.5 \mathrm{~b}$ & $2.5 \pm 0.5 \mathrm{~b}$ & $3.5 \pm 0.5 \mathrm{a}$ & $3.0 \mathrm{ab}$ \\
Purity of taste & $3.5 \mathrm{a}$ & $3.5 \mathrm{a}$ & $3.5 \mathrm{a}$ & $4.0 \mathrm{a}$ & $4.0 \mathrm{a}$ \\
Acid & $1.5 \mathrm{a}$ & $1.5 \mathrm{a}$ & $1.5 \mathrm{a}$ & $1.5 \mathrm{a}$ & $1.5 \mathrm{a}$ \\
Sweet & $2.0 \mathrm{a}$ & $2.0 \mathrm{a}$ & $2.0 \mathrm{a}$ & $2.5 \mathrm{a}$ & $2.0 \mathrm{a}$ \\
Bitter intensity & $2.5 \mathrm{a}$ & $2.5 \mathrm{a}$ & $2.5 \mathrm{a}$ & $3.0 \mathrm{a}$ & $2.5 \mathrm{a}$ \\
Quality of bitterness & $3.5 \mathrm{a}$ & $3.5 \mathrm{a}$ & $3.0 \mathrm{a}$ & $3.0 \mathrm{a}$ & $3.5 \mathrm{a}$ \\
Freshness & $3.5 \mathrm{a}$ & $3.5 \mathrm{a}$ & $3.5 \mathrm{a}$ & $3.0 \mathrm{a}$ & $3.5 \mathrm{a}$ \\
Fullness & $4.0 \mathrm{a}$ & $3.5 \mathrm{a}$ & $4.0 \mathrm{a}$ & $4.0 \mathrm{a}$ & $3.0 \mathrm{a}$ \\
Total acceptability & $4.0 \mathrm{a}$ & $3.5 \mathrm{a}$ & $3.5 \pm 0.5 \mathrm{a}$ & $3.5 \mathrm{a}$ & $4.0 \mathrm{a}$ \\
\hline
\end{tabular}

Means within the same attribute followed by a different letter are significantly different $(p<0.05)$. 
beers had little differentiation in terms of mouthfeel, including fullness and freshness. Regarding buckwheat beers, the taste was found to be comparable to that of $100 \%$ malted barley beer, although the bitter intensity was slightly higher. Beer bitterness is primarily produced by the hops, but also by some other bitter-tasting molecules, such as polyphenols and proteins [14]. Considering that the same hopping regime was used in our work, the slight differences in terms of bitterness may be attributed to the polyphenols and proteins from buckwheat malt. Furthermore, another observation regarding the final buckwheat beers was that they had a very distinct nutty flavor. However, they showed no obvious flavor defects. The results observed here were consistent with the aforementioned data of the above beer physicochemical analyses. Nic Phiarais et al. [15] brewed a top-fermented beer from 100\% buckwheat malt and found that the final product was quite comparable to a typical wheat beer in terms of odor, purity of taste, mouthfeel, and bitterness.

To conclude, the obtained results clearly indicate that the main beer quality attributes were mostly unaffected when replacing $20 \%$ or $40 \%$ malted barley with tartary buckwheat malt. The results of sensory analysis showed that the buckwheat beers were acceptable, particular in terms of odor, mouthfeel, and taste. Moreover, the rutin and total flavonoid content in the buckwheat beers depended strongly on the mashing programs. Compared to the common mashing process, the rutin and total flavonoid content in the buckwheat beers produced using the improved mashing method were about 60 and two times greater, respectively, when using the same amount of buckwheat malt. A good correlation was also obtained between antioxidant activity and rutin content or total flavonoid content in the buckwheat beers. The rutinenriched lager beers showed relatively high antioxidant capacity and oxidative stability during forced-aging.

\section{Acknowledgments}

This study was financially supported by the National Natural Science Foundation of China (no. 31801517), the Natural Science Foundation of Shandong Province (no. ZR2019BC010) and the Advanced Talents Foundation of Qingdao Agricultural University (No. 6631118039). This work was partially supported by the OTTOGI Corporation through the Research and Publication Project, by the Korean Institute of Planning and Evaluation for Technology in Food, Agriculture, Forestry, and Fisheries (IPET) through the Agriculture, Food and Rural Affairs Research Center
Support Program, funded by the Ministry of Agriculture, Food, and Rural Affairs (MAFRA) (D. Kim, 710012-03-1HD220), Republic of Korea. The present study has been also conducted by research grants (2018R1D1A1A09083366, D. Kim) of NRF, Republic of Korea.

\section{Conflict of Interest}

The authors have no financial conflicts of interest to declare.

\section{References}

1. Chul C, Wackerbauer K, Kang SA. 2007. Influence of aeration during propagation of pitching yeast on fermentation and beer flavor. J. Microbiol. Biotechnol. 17: 297-304.

2. Deng Y, Liu J, Li L, Fang H, Tu J, Li B, et al. 2015. Reduction and restoration of culturability of beer-stressed and low-temperature-stressed Lactobacillus acetotolerans strain 2011-8. Int. J. Food Microbiol. 206: 96-101.

3. Piazzon A, Forte M, Nardini M. 2010. Characterization of phenolics content and antioxidant activity of different beer types. J. Agric. Food Chem. 58: 10677-10683.

4. Zhao H, Chen W, Lu J, Zhao M. 2010. Phenolic profiles and antioxidant activities of commercial beers. Food Chem. 119: 1150-1158.

5. de Gaetano G, Costanzo S, Di Castelnuovo A, Badimon L, Bejko D, Alkerwi A, et al. 2016. Effects of moderate beer consumption on health and disease: a consensus document. Nutr. Metab. Cardiovas. 26: 443-467.

6. Romeo J, González-Gross M, Wärnberg J, Díaz LE, Marcos A. 2008. Effects of moderate beer consumption on blood lipid profile in healthy Spanish adults. Nutr. Metab. Cardiovas. 18: 365-372.

7. Fabjan N, Rode J, Košir IJ, Wang ZH, Zhang Z, Kreft I. 2003. Tartary buckwheat (Fagopyrum tataricum Gaertn.) as a source of dietary rutin and quercetin. J. Agric. Food Chem. 51: 6452-6455.

8. Zhang Z-L, Zhou M-L, Tang Y, Li F-L, Tang Y-X, Shao J-R, et al. 2012. Bioactive compounds in functional buckwheat food. Food Res. Int. 49: 389-395.

9. Oomah BD, Mazza G. 1996. Flavonoids and antioxidative activities in buckwheat. J. Agric. Food Chem. 44: 1746-1750.

10. Hosseinzadeh H, Nassiri-Asl M. 2014. Review of the protective effects of rutin on the metabolic function as an important dietary flavonoid. J. Endocrinol. Invest. 37: 783-788.

11. Jiang P, Burczynski F, Campbell C, Pierce G, Austria AJ, Briggs CJ. 2007. Rutin and flavonoid contents in three buckwheat species Fagopyrum esculentum, F. tataricum, and F. homotropicum and their protective effects against lipid peroxidation. Food Res. Int. 40: 356-364. 
12. Terpinc P, Cigić B, Polak T, Hribar J, Požrl T. 2016. LC-MS analysis of phenolic compounds and antioxidant activity of buckwheat at different stages of malting. Food Chem. 210: 9-17.

13. De Meo B, Freeman G, Marconi O, Booer C, Perretti G, Fantozzi P. 2011. Behaviour of malted cereals and pseudocereals for gluten-free beer production. J. Inst. Brew. 117: 541-546.

14. Deželak M, Zarnkow M, Becker T, Košir IJ. 2014. Processing of bottom-fermented gluten-free beer-like beverages based on buckwheat and quinoa malt with chemical and sensory characterization. J. Inst. Brew. 120: 360-370.

15. Nic Phiarais BP, Mauch A, Schehl BD, Zarnkow M, Gastl M, Herrmann M, et al. 2010. Processing of a top fermented beer brewed from $100 \%$ buckwheat malt with sensory and analytical characterization. J. Inst. Brew. 116: 265-274.

16. Wijngaard HH, Arendt EK. 2006. Optimisation of a mashing program for 100\% malted buckwheat. J. Inst. Brew. 112: 57-65.

17. Kreft I, Fabjan N, Yasumoto Y. 2005. Rutin content in buckwheat (Fagopyrum esculentum Moench) food materials and products. Food Chem. 98: 508-512.

18. He G, Du J, Zhang K, Wei G, Wang W. 2012. Antioxidant capability and potableness of fresh cloudy wheat beer stored at different temperatures. J. Inst. Brew. 118: 335-411.

19. Dong J, Li Q, Yin H, Zhong C, Hao J, Yang P. 2014. Predictive analysis of beer quality by correlating sensory evaluation with high alcohol and ester production using multivariate statistics methods. Food Chem. 161: 376-382.

20. Lee TK, Hanh Nguyen TT, Park N, Kwak SH, Kim J, Jin S, et al. 2018. The use of fermented buckwheat to produce Lcarnitine enriched oyster mushroom. AMB Express 8: 138.

21. Jia Z, Tang M, Wu J. 1999. The determination of flavonoid contents in mulberry and their scavenging effects on superoxide radicals. Food Chem. 64: 555-559.

22. Chen P, Gu J. 2011. A rapid measurement of rutindegrading enzyme activity in extract of tartary buckwheat seeds. Food Bioprod. Process. 89: 81-85.

23. Deng Y, Bi H, Yin H, Yu J, Dong J, Yang M, et al. 2018. Influence of ultrasound assisted thermal processing on the physicochemical and sensorial properties of beer. Ultrason. Sonochem. 40: 166-173.

24. Steadman KJ, Burgoon MS, Lewis BA, Edwardson SE, Obendorf RL. 2001. Minerals, phytic acid, tannin and rutin in buckwheat seed milling fraction. J. Sci. Food Agric. 81: 1094-1100.

25. Schnitzenbaumer B, Kerpes R, Titze J, Jacob F, Arendt EK. 2012. Impact of various levels of unmalted oats (Avena sativa L.) on the quality and processability of mashes, worts, and beers. J. Am. Soc. Brew. Chem. 70: 142-149.
26. Steiner E, Gastl M, Becker T. 2011. Protein changes during malting and brewing with focus on haze and foam formation: a review. Eur. Food Res. Technol. 232: 191-204.

27. Yasuda T, Nakagawa H. 1994. Purification and characterization of the rutin-degrading enzymes in tartary buckwheat seeds. Phytochemistry 37: 133-136.

28. Suzuki T, Yutaka H, Funatsuki W, Nakatsuka K. 2002. Purification and characterization of flavonol 3-glucosidase, and its activity during ripening in tartary buckwheat seeds. Plant Sci. 163: 417-423.

29. Vogrinčič M, Timoracka M, Melichacova S, Vollmannova A, Kreft I. 2010. Degradation of rutin and polyphenols during the preparation of tartary buckwheat bread. J. Agric. Food Chem. 58: 4883-4887.

30. Huang D, Ou B, Ronald L. 2005. The chemistry behind antioxidant capacity assays. J. Agric. Food Chem. 53: 1841-1856.

31. Schlesier K, Harwat M, Böhm V, Bitsch R. 2002. Assessment of antioxidant activity by using different in vitro methods. Free Radical Res. 36: 177-187.

32. Liu J, Li Q, Dong J, Chen J, Gu G. 2008. Multivariate modeling of aging in bottled lager beer by principal component analysis and multiple regression methods. J. Agric. Food Chem. 56: 7106-7112.

33. Tafulo PAR, Queirós RB, Delerue-Matos CM, Sales MGF. 2010. Control and comparison of the antioxidant capacity of beers. Food Res. Int. 43: 1702-1709.

34. Madigan D, Perez A, Clements M. 1998. Furanic aldehyde analysis by HPLC as a method to determine heat-induced flavor damage to beer. J. Am. Soc. Brew. Chem. 56: 146-151.

35. Vanderhaegen B, Neven H, Verachtert H, Derdelinckx G. 2006. The chemistry of beer aging - a critical review. Food Chem. 95: 357-381.

36. Ducruet J, Rébénaque P, Diserens S, Kosińska-Cagnazzo A, Héritier I, Andlauer W. 2017. Amber ale beer enriched with goji berries - the effect on bioactive compound content and sensorial properties. Food Chem. 226: 109-118.

37. Daenen L, Sterckx F, Delvaux FR, Verachtert H, Derdelinckx G. 2008. Evaluation of the glycoside hydrolase activity of a Brettanomyces strain on glycosides from sour cherry (Prunus cerasus L.) used in the production of special fruit beers. FEMS Yeast Res. 8: 1103-1114.

38. Slimestad R, Verheul M. Properties of chalconaringenin and rutin isolated from cherry tomatoes. J. Agric. Food Chem. 59: 3180-3185.

39. Yang J, Guo J, Yuan J. 2008. In vitro antioxidant properties of rutin. LWT-Food Sci. Technol. 41: 1060-1066. 